\title{
AN ATTEMPT TO EXEMPLIFY THE ECONOMIC PRINCIPLES IN REAL PROPERTY VALUATION
}

\author{
Ewa Kucharska-Stasiak, prof. \\ Faculty of Economics and Sociology \\ University of Lodz \\ e-mail: ewkuchar@uni.lodz.pl \\ Sabina Źróbek, prof. \\ Faculty of Geodesy, Geospatial and Civil Engineering \\ University of Warmia and Mazury in Olsztyn \\ e-mail:zrobek@uwm.edu.pl
}

\begin{abstract}
The economic theory argues that the value of assets, including the value of real property, is influenced by many factors which determine the behavior of operators engaged in market transactions. The knowledge of basic principles and assumptions which underpin the development of value is essential to understanding the methods and procedures of valuation. The thesis, upon which the authors of this article based their theoretical and practical considerations, is formulated as follows: "The knowledge of economic principles of valuation improves the accuracy of valuation and allows for more appropriate interpretation of its results". Therefore, these factors should be taken into account by appraisers estimating the value of property. Over a dozen so-called key principles of valuation have been formulated in literature. Among them are the principles of anticipation, change, substitution, supply and demand, competition, balance, highest and best use, conformity, and externalities. It is assumed that the most important principle in the valuation of property is the principle of anticipation. Some of the principles are relevant to all the traditional approaches to determining value, while others apply only to selected approaches e.g., the principle of opportunity cost, which is mainly used in valuations using the income approach. The thesis is supported by research results and an analysis of practical examples.
\end{abstract}

Key words: value of property, valuation principles, economy theory of valuation.

JEL Classification: R3, D46.

Citation: Kucharska-Stasiak E., Źróbek S., 2015, An Attempt to Exemplify the Economic Principles in Real Property Valuation, Real Estate Management and Valuation, Vol. 23, No. 3, pp. 5-13.

DOI: $10.1515 /$ remav-2015-0020

\section{Introduction}

In Poland, the term "Valuation" means the procedure which results in determining the value of the property (USTAWA ... 1997). On the international stage, this term is used to describe both the activities of the real estate appraiser and the outcome of these activities (MIĘDZYNARODOWE ... 2011, EUROPEJSKIE ... 2013). The principles of property valuation, including the classification and definition of the methods of valuation, are set out in the Act on Real Estate Management and in the Polish Regulation of the Council of Ministers on the valuation of property and the preparation of the appraisal (ROZPORZĄDZENIE ... 2004). These two laws constitute the obligatory legal basis for valuation. They also provide the factors to be taken into account when choosing a property similar to that being appraised. These include, e.g.: the type of property rights, technical condition, use and location of the 
property, and its assignment in the spatial development plan (zoning plan) (USTAWA ... 1997). Factors such as economic determinants and motivations of the parties to the transaction were not included in the regulations. However, we all agree that the property valuation process requires interdisciplinary knowledge, including, inter alia, knowledge of the law, and technical and economic sciences. The long list of factors which affect the value of property can be divided into four basic categories: social, economic, governmental, and environmental. Economic factors play a leading role among them. It is worth noting that the roots of the theory of the valuation of assets, including real estate, is to be found in economic theory. The concept of value is, in fact, interpreted as the most probable price of a commodity determined by the buyers and sellers and reflecting the market's view of the economic benefits resulting from its ownership (MIĘDZYNARODOWE ... 2011, p.2). Hence the need for the knowledge of economic principles of valuation and to include these principles in the procedures for determining different types of real estate values, and especially the market value. The failure to take into account the actions of economic theory in the practice of valuation often resulted in the fact that the market value determined by the appraiser was not confirmed in the real estate market.

\section{Thesis, purpose of the research and the method of its implementation}

The complaints about incorrect appraisals inspired us to show how economic principles work in relation to the valuation of property. Most often, such complaints concerned the wrong level of market value.

The thesis, underlying theoretical and practical considerations, is formulated as follows: "The knowledge of economic principles of valuation improves the accuracy of valuation and allows for more appropriate interpretation of its result."

The aim of the discussion was to provide definitions of selected economic principles of valuation and their interpretation in relation to the real estate market, as well as demonstrate their applicability in the methodology and well-understood practice of valuation.

For this purpose, we quoted some important items of literature from the field of knowledge under study. The practical examples refer to studies published by other authors as well as our own experience.

\section{Valuation principles in research and practice of a real estate appraiser}

Literature on the subject mentions over a dozen economic principles, which, according to property valuation methodologists, should be taken into account in the process of appraisal. Most frequently, four key principles of appraisal are mentioned: anticipation, change, substitution, and contribution. However, the authors of many studies present more extensive lists, adding even further principles, such as supply and demand, competition, opportunity cost, balance (equilibrium), highest and best use, surplus productivity, conformity, and externalities.

Some of the principles are relevant to all the traditional approaches to determining the value, e.g. the principle of substitution, others only to the selected approaches, e.g. the principle of opportunity cost, which is mainly used in the income valuation approach. The role of these principles in the valuation methodology will be demonstrated later in this work.

The definitions of these principles discussed in this article are taken from the Polish edition of the manual (THE APPRAISAL ..., 2000). When other sources were used, it was indicated in the text. There is a uniform view in literature that the most important principle in the valuation of property is the principle of anticipation. It reveals that value is created by the anticipated benefits which can be obtained in the future from a particular asset. The buyer of a real estate like an investor in the securities market is not buying the past or the present but the future, understood e.g., as future dividends and capital gains. The real estate market participant can measure the value of the property he is buying as the current value of future benefits, including intangible benefits. Data relating to real estate and the real estate market from the past are useful only if they help to interpret the current predictions about the market, predictions concerning the demand for the appraised property. A property buyer expects to benefit from the ownership of a property, e.g. from the right of residence, from the right to achieve benefits in the form of income generated by the property, from the right to its value increasing in the future or the right to tax relief. Expectations concerning these benefits affect the preferences of buyers, creating demand. The higher the quality of the purchased goods and the longer the estimated time of obtaining benefits, the higher the value of the property. 
The effects of the principle of anticipation for the real estate market have been shown, e.g. in the article "Value influencing mechanism of green certificates in the discounted cash flow valuation" (VIMPARI and JUNILLA 2014). In this study, the value influencing mechanism of green certificates in property investment was researched. The goal was to understand the value influencing mechanism and, more deeply, to identify the differences in DCF parameters between certified properties and noncertified properties. The results show that a green certificate, on average, increases the property value by $9.0 \%$ in the DCF valuation model. Improved yield and net rental income were the main reasons for the higher property value.

The principle of anticipation can be reflected in situations which took place in the Polish housing market. For example, at the beginning of 2015, there was an increase in the selling prices in a certain segment of residential apartments in Olsztyn despite the general price stability. Closer analysis showed that this increase was mainly due to an increase in the cost of construction of new houses built in energy-saving technology. However, buyers accepted these prices by opting to pay a higher price in anticipation of future lower home heating costs.

The principle of anticipation makes the prices of residential premises in a prefabricated building lower than the prices of apartments similar in terms of location, layout and area, but located in buildings constructed using traditional methods. According to its users, their pricing decisions were influenced by two main factors - a lower comfort of living and the awareness that their property will depreciate along with the increasing stock of higher quality. To provide another example, tenants, competing with each other, signed lease agreements for commercial premises in a shopping mall under construction agreeing to higher than average rental rates in similar shopping centers. They assumed that the location of the mall, encouraging the arrival of customers from across Poland's eastern border, will compensate for the higher rent and that they will make a fair profit on the sale of goods.

However, it should be emphasized that the principle of anticipation does not mean that the appraiser in the valuation process should create the future. The appraiser should portray both, the market on the valuation day and current expectations of market participants about the future.

The principle of change means that the change in the value of the property is the result of the changes taking place within and between interrelated forces affecting this value. The changes may involve ones within the cadastral boundaries of the property being valued. Also the environment of the real estate can change, involving changes in the economic environment (variable economic conditions, unemployment, inflation), financial environment (changes in interest rates, the tendency of banks to finance the real estate market), political environment (the level of corruption in the country, the strength of trade unions), legal environment (changes in laws governing freedom to participate in transactions, tax reliefs, the rules for calculating depreciation, planning) and demographics (population decline in the city). These changes affect the demand and supply of real estate and consequently its value. The impact of the demographic factor on real estate prices was examined, inter alia, by Renigier-Biłozor and Wiśniewski. The authors consider that variables: UE - the increase in the unemployment variable and PG - the population growth variable (based on Eurostat data) have the most important influence on Residential Property Price Indices in Poland.

The significant variables for Poland, i.e. unemployment rate and population growth, are characteristic of developing countries and constitute a very important factor influencing the demand for real estate, and thus its price (RENIGIER-BIŁOZOR and WIŚNIEWSKI 2013).

The result of studies on the effects of the financial crisis on the housing market (WANG and ZHANG 2013) is an example of the impact of this principle. The authors have been investigating the recent financial crisis with an emphasis on the connection between the housing, mortgage and credit markets, using a model in which both, the prices of the mortgage and its collateral, are simultaneously and endogenously determined. In their opinion, the empirical tests confirm the model's prediction that an adverse change in the risk free rate or the loan recovery rate can trigger a financial crisis.

The need to take into account political risk is an example of the impact of the principle of change. The difficult situation and developments in Ukraine led to a significant decline in the number of customers in one of the shopping malls located in the north-eastern part of Poland. Some tenants of commercial premises (especially in the footwear business) began to renegotiate their leases to reduce rents at the beginning of 2015. Consequently, this may result in a lower profitability of the facility and a decline in its market value. 
The principle of supply and demand means that there is a close relationship between the volume of real estate demand and supply and the price paid on the real estate market. This rule relates to the factors of utility, scarcity, desire and effective purchasing power. In the short term, an increase in demand leads to higher prices and stimulates the developers' market. However, changes in supply in this market are slower than changes on the demand side. The stronger is the increase in prices, the stronger is the reaction on the side of the developers' market, driven by expected profits. This can lead to oversupply, which results in lower prices, thus a decline in profits for the developers. A low price level may encourage investors to enter the market, and consequently, the oversupply will be slowly absorbed. The number of potential buyers, their purchasing power, tastes and preferences shape real estate prices in the various segments of the real estate market.

The need to project the impact of the rule of supply and demand on the value may be confirmed by the following situation: in one of the cities in Poland, just before the valuation date, a large public entity put about 90 plots for residential buildings up for sale. This resulted in an unexpected oversupply in the local real estate market. The appraiser did not take this fact into account and set the value of one square meter of these plots too high. The owner was forced to issue a second invitation to tender and lower the price. He also lost the opportunity to initiate a project which was to be financed from the funds obtained from the sales of these land parcels on time.

The principle of change is closely related to the principle of competition, i.e. "... every real estate competes with other real estates which can be utilized in the same way". Also sellers and buyers compete with each other as well as owners and tenants (lessees). Competition stimulates supply and demand. Competition among buyers of property rights leads to an increase in the prices of properties, stimulating supply; competition among the sellers of these rights does not allow for prices to be raised prices, which may have a positive impact on demand. Awareness of the principle of competition and its effect on value requires analyzing the supply of existing competitive real estates as well as new real estates. Strong competition will reduce the stream of income generated by the valued real estate and decrease the chance of obtaining income, despite the high standard of the real estate and a positive economic background. This means that in a competitive market, very high returns on a real estate on the valuation date cannot be sustained in the future. For example, while valuating a property with two twelve-storey prefabricated hotel buildings exhibiting a high degree of technical and functional wear, the property valuer anticipated the need for their renovation and modernization. As a result of expected large expenditures, the value of this property determined by the property valuer was not set at a high level. Even after a major renovation and modernization, the competition on part of the refurbished and upgraded hotels and newly erected ones requires disclosing the increasing risk of income in the future in the valuation.

Another important principle is the principle of substitution, which in relation to the real estate market can be defined as follows: "when similar real estates are available in the market, the buyer will not pay more for a particular real estate than for a similar real estate." The substitution may be considered from the point of view of how the property is to be used, of the cost of purchasing land and constructing a building or of the cost of purchasing the developed property, or from the point of view of expected income. Determining the amount of rent and the rates of return on investments in real estate should be based on market rents and rates of return on investments in similar real estates. This principle also discloses that the price of a real estate largely depends on whether it is possible to purchase a property comparable in terms of utility within the acceptable period of time.

The following example can illustrate the principle of substitution on the market. A property with a new residential house was valued on a detached housing estate. There were also undeveloped plots for sale in the housing estate. The owner sold the property at a price which was about $10 \%$ higher than the total value of the land and the cost of building a house, based on market value determined by a property valuer. The undeveloped plots of land were a substitute which allowed the buyer to negotiate a fair purchase price for the property. He agreed to pay this price to avoid the necessary involvement in the construction process. The analysis of prices of real estates developed with residential houses and the market costs of building these houses allowed the property valuer to accurately estimate the market value of the property being valued.

The principle of opportunity cost is an important economic principle, understood as the cost of potentially lost opportunities (or as the cost of lost benefits). Real estate as an investment object competes with other investments which are characterized by different levels of risk and different levels of rate of return. "A well informed investor will choose this type of investment which provides for the 
highest return at the lowest level of risk". The theory of opportunity cost makes both demand and supply dependent on utility (BLAUG 1994, p. 497). An investment in real estate is a more useful direction of investing, because one can expect a higher rate of return than on treasury bonds. This principle is useful for deriving the discount rate for the valuation of real estate in markets without data. The property valuer adjusts the safe rate of return (the rate on treasury bonds) by a mark-up resulting from the risk of investing in a particular segment or spatial segment of the real estate market in the best real estate and by a mark-up due to the risk of investing in the valued real estate. The rate of return on bonds is the opportunity cost, or the cost of lost opportunities. The proper understanding of the concept of the market value of a property requires knowledge of the principle of balance. It is based on the ascertainment "... that the value is generated and maintained when the opposite elements, mutually affecting each other and contrasting with each other, are in the state of equilibrium."

The state of equilibrium is determined by the optimum combination of two components: land and buildings. A large area of land developed with a small building or valuable land with technically and functionally worn buildings not accepted by the tenants are examples of inefficient management. It may turn out that the value of the developed land will be lower than the value of the land itself. In this extreme case, the buildings will reduce the value of the real estate. One can consider the following two extreme initial positions:

1. An excess of land occurred in relation to the value of the developed property. This demonstrates the internal imbalance and indicates the need to restore it by separating the unnecessary, undeveloped part of the real estate in order to sell it, or by intensifying development.

2. The land was properly used at the stage of its development. This means that the internal balance was maintained. However, even in this situation it may again be disturbed when:

a) Due to technical and functional wear, the value of buildings decreases and the value of land remains unchanged. This means that the land is not used properly. Buildings should be either demolished and the area should be developed with new facilities or should be renovated and modernized, in order to restore the balance between the land and capital.

b) Due to an increase in prices on the real estate market the relative proportion between the buildings and the value of the land is changing. In the case of rising prices on the market, the value of the land may grow faster than the value of developed property. The proportion between the value of land and the value of buildings is disturbed. The more susceptible the buildings are to technical and functional wear, the sooner the internal balance is disturbed. A property with office space or a developed property with high-technology facilities will require actions to restore the balance much sooner. These actions may involve necessary renovation and modernization, often involving changes in the function of the property.

Examples derived from the practice of real estate valuation are described below, confirming the work of the principle of internal balance. The first situation: valuation involved developed real estate with a large residential house with a swimming pool; the total building area was slightly smaller than the plot on which the house was built. The property valuer had to take this fact into account in the valuation process, because potential buyers feared that a too small area of the plot would not guarantee comfortable living conditions.

This principle also means that overinvestment in buildings can decrease the profitability of the property. The calculations should take into account both the volume of the invested capital and further operational expenses related to the maintenance of the property. This is shown by the following example: a guest house in the style of a "ranch" with many items of small architecture for specialized recreation was the subject of valuation conducted in order to sell the property. Unfortunately, the appraiser did not take into account in the valuation the fact that the too small area of the plot of land and the immediate industrial neighborhood of the real estate decrease the attractiveness of this offer to potential vacationists. Potential buyers were not interested in this real estate because of the low use of the property and the high cost of maintaining it. Real estate agents could not sell the property for a long time, until its price was lowered by almost $1 / 5$ of its previous value.

In turn, the principle of conformity reminds us that: 1 . It is not the land and building isolated from space that are the subject of evaluation, but the property which is part of the space in which mutual interactions occur. 2. Properties, which are unusual in terms of land or building size, architectural 
style or age, will lose their value as a result of other standards found in their vicinity. Ratterman quotes a saying known in the real estate industry: "unique property" means that no one else will want to buy it (RATTERMANN 2009). This principle is confirmed by the following practical example. It was necessary to determine the value of land under roads in order to update the lease (perpetual usufruct) payments for the land. The immediate surroundings of the plots valued consist of plots developed with office and industrial buildings, as well as warehouses and depot areas. Because "road" transactions are scarce, the property valuer analyzed the relationship between the price of a square meter of the "road" and the price of adjacent land, supported by these roads. The analysis showed that such a relationship exists. In this case the unit prices of the "road" land adjacent to the land intended for warehouses were about $16 \%$ lower than "road" land which served areas for detached housing, and lower by $9.7 \%$ on average than land earmarked for roads which were to serve areas for trade and services (OPINIA ... 2013). On the other hand, Brzezicka and Wiśniewski (2014) confirmed the existence of information conformity in the system of the real estate market. Information conformity determines the price level because a group is convinced about the price. Information conformity exhibits the tendency of market operators to follow in the footsteps of the group. This may lead to dangerous social and economic phenomena at the macro level, but also has consequences for the real estate market system in the form of anomalous phenomena, e.g. fluctuation of prices, uncontrolled by the market. The principle of balance and principle of conformity are closely related to the principle of highest and best use. This principle, in Poland, was called the principle of the most effective use of the property. On the grounds of international standards, the highest and best use is defined as "... the use of an asset that maximizes its productivity and that is possible, legally permissible and financially feasible" (MIĘDZYNARODOWE ... 2011, p. 36). The previously discussed disturbed internal balance, i.e. the balance between the value of the land and the value of buildings or between the value of the developed property and the value of the land, should be a signal to look for the highest and best use of the real estate. Disturbed external balance may also be a reason to look for the highest and best use. This motivates a property valuer to draw up principles for the valuation in order to restore the disturbed equilibrium. The principles may involve the need to carry out extensive repairs, modernization, expansion, changes in the function and even demolition of the existing buildings in order to prepare the land for new investment. This means that valuation must disclose the potential of the real estate. This is consistent with the behavior of market participants. The demolition of a relatively new commercial building in Warsaw is a good example of the practical application of the highest and best use. The building was in very good condition and located at Zlota Street. The high price of land in relation to the profitability of a small shopping centre (disturbed internal balance) was the basis for the demolition of the building and providing land for the construction of a new apartment building in which the lowest apartment price per square meter exceeded 20 thousand zlotys. It should also be noted that the principle of the highest and best use is applied not only to estimate the market value of the property, but also in the broadly understood consulting in the real estate market.

One of the principles of economics is the principle of diminishing returns ${ }^{1}$, which in the real estate valuation theory is called the "principle of diminishing marginal productivity." This principle reveals that "... the value of production factor or component of property depends on the extent to which it has a share in the whole or the extent to which its absence causes a loss to the whole" (THE APPRAISAL... 2000, p. 63). The value of additional investment must be measured as the difference between the value of the property which has the attribute and the value of the property which does not have it.

This principle is well understood by developers who offer uncompleted apartments, with no floors, internal doors, door frames and wall finishing. They do this not only because the tastes of buyers are diverse, but also because the costs of completing apartments is too high, raises the price of the product, and may hinder or stop the sale. The costs incurred by the developers will not translate proportionally into the increase in income.

Another principle, the principle of additional income is identified with a surplus which is left "... after paying all payments related to the operation and after satisfying / repaying capital invested in buildings". This surplus determines the value of the land. Disclosure that the value of the land is equal to what is

\footnotetext{
1 This principle, also known as the law, shows that from a certain level of expenditure of a given factor which is a variable in the model, its marginal productivity decreases for every subsequent unit of the factor the increase in production is diminishing. This law is formulated assuming ceteris paribus, all other factors being constant.
} 
left, means that it is not the value of the land that determines the intensity of building, but that the intensity is determined by changes in the cost of construction and in the market value of the developed property (FRASER 1993).

In turn, the observed relationship between the property and its environment was the impulse to formulate the principle of conformity. The principle informs us that "... the value of the property is created and is maintained when the characteristics of the property in question are tailored to the requirements of the market." If an investor invests capital which is disproportionate in relation to the character of the environment and neighbourhood, this capital will probably be spent inefficiently. The value of real estate of a high standard usually falls in relation to the value of similar properties in the neighborhood. There may even be cases when the "worse" property reaches the value of the "better" properties surrounding it.

The level of the market value of a property is, to a large extent, determined by external factors. This fact justifies taking into account the principle of externalities in the valuation of real estate. These factors are considered as a background affecting the value. These externalities include: social factors, including demographic factors, economic factors affecting the demand and supply of real estate, institutional factors, such as regulations on, e.g. rental policy, fiscal and tax policy, credit policy, environmental factors, including the climate, terrain, soil quality assessment, land pollution, transportation links, and the international situation.

In the practice of property valuation, this principle means that the type and condition of the development of the real estate's environment (externalities) differentiate assessments given to qualities according to which the attractiveness of a location is compared. Many studies have confirmed the impact of, e.g. noise on lowering the price (value) of the property under its influence (...). More detailed research has also been conducted in order to determine which, road traffic or rail traffic, has a greater negative effect on property prices (ANDERSSON et al. 2010).

The correlation between the quality of selected elements of the environment and property prices was confirmed in their studies by Cellmer, Senetra and Szczepańska. Their analysis identified key environmental factors affecting property prices, i.e. greenery, surface water, noise impacts and landscape features. The surveyed sites were undeveloped land plots in the suburbs of Olsztyn (Poland). Correlation and regression analyses indicate that the attributes indicative of water bodies and forest cover were significantly correlated with transaction prices at a significance level below 0.05 . The correlation with land elevation features reached only 0.07 , and was non-significant. The similarity of results presented in the form of a multiple regression model suggests that the presence of water bodies and forests has a significant impact on transaction prices. In this case the significance level was below 0.005 (CELLMER et al. 2012).

The analysis of the prices of land and apartments located in different residential districts of Olsztyn, conducted in order to detect the factors differentiating their prices, revealed the practical impact of the principle of externalities on the valuation practice. In the case of apartment prices, the most important is the safety and status of residents, fashion, and the standard of the buildings (prefabricated or traditional construction) (CELLMER et al. 2004).

One more principle of valuation can be found in "A Real Estate Guide" - the principle of a fourstage life cycle. The use of this principle in real estate valuation is justified because, according to the authors, all material things go through the process of wearing or wasting away and eventually disintegrate. All properties are characterized by four distinct stages: growth, stability, decline, and revitalization (A REAL ESTATE...).

\section{Summary and Conclusions}

The analysis showed that the economic valuation principles described in literature are functional. Some of these principles are found in the methodology of valuation, others in good practice. Some of them are reflected by the market in prices, others, such as the principle of internal balance or highest and best use, require the property valuer to specify relevant assumptions.

The principle of anticipation, regarded as the basic economic principle of valuation, is mainly used in the comparative and income approach. This principle is evident in the comparative approach when market data reflecting the collective behavior of market participants are adopted during the period closest to the valuation date. 
In the income approach, this principle is reflected in constructing models of income generated by the property: infinitely constant income model at the market level at the valuation date or variable model for a certain period of income stream for a property undergoing changes, e.g. repairs, modernization or a new property launched into the market.

The substitution principle is represented in all approaches in property valuation, because it can be considered from the point of view of the way of usage, costs of construction and income received. However, this principle is most evident in the comparative approach.

It is worth noting that the market of similar properties (substitutes) can also be used to verify the reliability of the assumptions and numerical values used in calculations in the valuation process.

The principle of change applies to all approaches. Because the changes are continuous, the value is a dynamic category. Therefore, the level of the estimated value refers to the date on which it was determined. It should be noted that that the higher the uncertainty of expected changes, the more it should be reflected in higher rates of return. The operation of this principle is also reflected in a provision of the Polish Law on real estate concerning the updating of the valuation report.

The prices and, therefore, the value of a real estate depend on the size, proportion, and structure of supply and demand. The supply of properties means their relative scarcity, which is a key factor in creating value. However, since it is difficult to adjust supply in the short term, demand has the biggest effect on value. To conduct valuation on a given day we must assume that supply is constant.

The principle of opportunity cost is useful for the valuation of real estate in the income approach, to derive (estimate) the minimum rate of return (discount rate), required by investors, necessary to attract capital. A property valuer will reach for this concept, if he does not receive the relevant data from the real estate market. In the valuation methodology the opportunity cost is the profitability of 5or 10-year treasury bonds that provide for a fixed yield. The profitability of treasury bonds was adopted because of the desire to make investing in real estate resemble investing in the bond market.

Failure to include the principle of balance (internal and/or external) in the valuation, e.g. incorrect proportions of the value of land and value of buildings, would mislead customers. Valuation should reflect the behavior of market participants, mainly buyers. The requirement for the efficient use of scarce resources means that value should be determined assuming internal balance, which requires a reasonable combination of the value of land and expenditures needed for investing in the land.

The principle of diminishing marginal productivity of investment is very important in the process of real estate valuation. Its usefulness is evident in the comparative approach, but also in the income and cost approach. This principle reveals that the difference between the market value of a completed investment and the market value of the same facility under construction cannot be identified with the amount of expenditure necessary to complete the construction. This fact is of particular importance when valuation concerns a property under construction and is conducted in order to secure the lender's money.

The principle of additional income is the basis of the residual method of valuation', also called the developer's method. It can be used to estimate the value of land, but also, the value of maximum investment that can be incurred at the required level of profit, at the assumed purchase price of land, and at projected revenues.

A review of literature and analysis of practical examples show that many of the economic principles of valuation are interrelated. For example:

The principle of anticipation is strongly related to the principle of change, because the decisions concerning the different changes must take into account estimates concerning the future. Usually, market conditions in the future will not be the same as today. The more difficult and slower the rate of transformation (adjustments), the more the current decisions must take into account not only the current but also future, long-term conditions (BEGG et al. 1993).

The principle of balance is strongly related to the principle of conformity, additional income and highest and best use. An imbalance between the value of the land and the value of buildings, between expenditures incurred for the given property and expenditures incurred on neighboring properties, should be a signal for the property valuer to seek the highest and best use of the property.

\footnotetext{
2 The residual method was originated by D. Ricardo who developed the theory of distribution, also known as the residual theory.
} 
The impact of the use of economic principles in property valuation on the accuracy of the value of a particular property, documented by research and practical examples, confirms the initial thesis that knowledge of economic principles of valuation improves the course of the valuation procedure and allows for proper interpretation of its results.

\section{References}

A Real Estate Guide, chapter 15, Appraisal and Valuation, California Department of Real Estate Valuation, , www. ref15.pdf.dre.ca.gov [16.02.15]

ANDERSSON H., JONSSON L., ÖGREN M., 2010, Property Prices and Exposure to Multiple Noise Sources: Hedonic Regression with Road and Railway Noise, Environmental Resource Economic Springer Science, 45 , pp. 73-89.

BegG D., FISCHER S., DORnbusch R., 1993, Ekonomia, Państwowe Wydawnictwo Ekonomiczne, Warszawa, Volume 1.

BlaUG M., 1994, Teoria ekonomii. Ujęcie retrospektywne, Wydawnictwo Naukowe PWN, Warszawa.

BRZEZICKA J., WIŚNIEWSKI R., 2014, Wybrane postawy uczestników rynku wobec braków informacyjnych na rynku nieruchomości, Ekonomia XXI wieku, 2 (2), pp. 106-121.

CELLMER R., KORZUN A., KURYJ J., 2004, Identyfikacja i ocena czynników wptywajacych na przestrzenne zróżnicowanie popytu na nieruchomości mieszkaniowe, Studia i Materiały Towarzystwa Naukowego Nieruchomości, 12 (1), pp. 41-58.

CELLMER R., SENETRA A., SZCZEPAŃSKA A., 2012, Land Value Maps of Naturally Valuable Areas, Geomatics and Environmental Engineering, 6 (3), pp. 15-24, DOI:10.7494/geom.2012.6.3.1.5.

Europejskie Standardy Wyceny 2012 wydanie siódme, PFSRM, TEGoVA, Warsaw 2013.

FRASER W.D., 1993, Principles of Property Investment and Pricing, The Macmillan Press Ltd., London.

Międzynarodowe Standardy Wyceny 2011, 2011, Polska Federacja Stowarzyszeń Rzeczoznawców Majątkowych, Komitet Międzynarodowych Standardów Wyceny, Warsaw.

Opinia dotycząca wartości rynkowej gruntów, 2013, Katedra Gospodarki Nieruchomościami i Rozwoju Regionalnego,UWM,Olsztyn unpublished manuscript.

RATTERmAnN M.R., 2009, The Student Handbook to The Appraisal of Real Estate, $13^{\text {th }}$ Edition, Chicago.

RENIGIER-BIŁOZOR M., WIŚNIEWSKI R, 2013, The impact of macroeconomic factors on residential property prices indices in Europe, Folia Oeconomica Stetinensia Szczecin. 2 (12), pp. 103-125.

Rozporządzenie Rady Ministrów z dnia 21 września 2004 r. w sprawie wyceny nieruchomości i sporządzania operatu szacunkowego Dz.U. 2004 nr 207 poz. 2109 z późniejszymi zmianami. [Regulation of the Council of Ministers of 21 September 2004. On the valuation of the property and the preparation of the valuation report, Journal of Laws 2004 No. 207, item. 2109, as amended.]

The Appraisal of Real Estate, Chicago, Illinois, Appraisal Institute, Polish Edition, 2000 (Wycena nieruchomości, Wydanie polskie (wyd. PFSRM)).

Ustawa z dnia 21 sierpnia 1997 r o gospodarce nieruchomościami. Dz.U. $1997 \mathrm{Nr} 115$ poz. 741 z późniejszymi zmianami [The Act of 21 August 1997. On Real Property Management Journal of Laws 1997 No. 115, item 741 as amended.]

VIMPARI J., JUNILLA S., 2014, Value influencing mechanism of green certificates in the discounted cash flow valuation, International Journal of Strategic Property Management, 3 (18), pp. 238-252

WANG A.F., ZHANG T., 2013, Financial Crisis and Credit Crunch in the Housing Market. The Journal of Real Estate Finance and Economics 2 (49), pp. 256-276.

WiLsON D. C., 1998, Principle of production: a logical premise for the cost approach, The Appraisal Journal, January 25-40. 